\title{
Cost-effectiveness of feeding strategies to reduce greenhouse gas emissions from dairy farming
}

\author{
C. E. Van Middelaar, ${ }^{\star 1}$ J. Dijkstra,† P. B. M. Berentsen,‡ and I. J. M. De Boer \\ *Animal Production Systems group, Wageningen University, PO Box 338, $6700 \mathrm{AH}$ Wageningen, the Netherlands \\ †Animal Nutrition group, Wageningen University, PO Box 338, $6700 \mathrm{AH}$ Wageningen, the Netherlands \\ łBusiness Economics group, Wageningen University, PO Box 8130, 6700 EW Wageningen, the Netherlands
}

\section{ABSTRACT}

The objective of this paper was to evaluate the costeffectiveness of 3 feeding strategies to reduce enteric $\mathrm{CH}_{4}$ production in dairy cows by calculating the effect on labor income at the farm level and on greenhouse gas (GHG) emissions at the chain level (i.e., from production of farm inputs to the farm gate). Strategies included were (1) dietary supplementation of an extruded linseed product ( $56 \%$ linseed; $1 \mathrm{~kg} /$ cow per day in summer and $2 \mathrm{~kg} /$ cow per day in winter), (2) dietary supplementation of a nitrate source (75\% nitrate; $1 \%$ of dry matter intake), and (3) reducing the maturity stage of grass and grass silage (grazing at 1,400 instead of $1,700 \mathrm{~kg}$ of dry matter/ha and harvesting at 3,000 instead of $3,500 \mathrm{~kg}$ of dry matter/ha). A dairy farm linear programing model was used to define an average Dutch dairy farm on sandy soil without a predefined feeding strategy (reference situation). Subsequently, 1 of the 3 feeding strategies was implemented and the model was optimized again to determine the new economically optimal farm situation. Enteric $\mathrm{CH}_{4}$ production in the reference situation and after implementing the strategies was calculated based on a mechanistic model for enteric $\mathrm{CH}_{4}$ and empirical formulas explaining the effect of fat and nitrate supplementation on enteric $\mathrm{CH}_{4}$ production. Other GHG emissions along the chain were calculated using life cycle assessment. Total GHG emissions in the reference situation added up to $840 \mathrm{~kg}$ of $\mathrm{CO}_{2}$ equivalents $\left(\mathrm{CO}_{2} \mathrm{e}\right)$ per $\mathrm{t}$ of fatand protein-corrected milk (FPCM) and yearly labor income of $€ 42,605$. Supplementation of the extruded linseed product reduced emissions by $9 \mathrm{~kg}$ of $\mathrm{CO}_{2} \mathrm{e} / \mathrm{t}$ of FPCM and labor income by $€ 16,041$; supplementation of the dietary nitrate source reduced emissions by 32 $\mathrm{kg}$ of $\mathrm{CO}_{2} \mathrm{e} / \mathrm{t}$ of FPCM and labor income by $€ 5,463$; reducing the maturity stage of grass and grass silage reduced emissions by $11 \mathrm{~kg}$ of $\mathrm{CO}_{2} \mathrm{e} / \mathrm{t}$ of $\mathrm{FPCM}$ and la-

Received October 28, 2013.

Accepted December 9, 2013.

${ }^{1}$ Corresponding author: Corina.vanMiddelaar@wur.nl bor income by $€ 463$. Of the 3 strategies, reducing grass maturity was the most cost-effective $\left(€ 57 / \mathrm{t}\right.$ of $\mathrm{CO}_{2} \mathrm{e}$ compared with $€ 241 / \mathrm{t}$ of $\mathrm{CO}_{2}$ e for nitrate supplementation and $€ 2,594 / \mathrm{t}$ of $\mathrm{CO}_{2}$ e for linseed supplementation) and had the greatest potential to be used in practice because the additional costs were low.

Key words: life cycle assessment, profitability, fat supplementation, grass quality

\section{INTRODUCTION}

Methane $\left(\mathrm{CH}_{4}\right)$ production from enteric fermentation in dairy cows is not only an energy loss for the animal (i.e., about $6 \%$ of the gross energy intake is lost as $\mathrm{CH}_{4}$ ), but is also an important contributor to greenhouse gas (GHG) emissions (Ellis et al., 2008). Enteric $\mathrm{CH}_{4}$ is responsible for about $50 \%$ of the total amount of GHG emissions along the production chain of milk, whereas other important GHG emissions are the emission of carbon dioxide $\left(\mathrm{CO}_{2}\right)$ and nitrous oxide $\left(\mathrm{N}_{2} \mathrm{O}\right.$; Hörtenhuber et al., 2010). Reducing enteric $\mathrm{CH}_{4}$ production, therefore, is seen as an effective way to reduce GHG emissions from milk production.

Enteric $\mathrm{CH}_{4}$ derives from microbial fermentation of feed substrates in the rumen (92\%) and large intestine (8\%; Bannink et al., 2011). The production of $\mathrm{CH}_{4}$ is influenced by dietary factors, such as type and amount of feed; animal factors, such as milk yield and genetic traits; and environmental factors, such as temperature (Kebreab et al., 2006; Hristov et al., 2013b). Examples of feeding strategies that have been proposed to reduce enteric $\mathrm{CH}_{4}$ are dietary supplementation of FA, dietary supplementation of nitrate, and reducing the maturity stage of grass and grass silage (Sterk et al., 2010; van Zijderveld et al., 2011; Brask et al., 2013). Martin et al. (2008) showed that supplementation of extruded linseed to achieve a dietary fat content of $5.7 \%$ reduced enteric $\mathrm{CH}_{4}$ from 19.3 to $14.8 \mathrm{~g} / \mathrm{kg}$ of FCM. Supplementation of a nitrate source ( $75 \%$ nitrate; $2.1 \%$ of dietary DM) was found to reduce enteric $\mathrm{CH}_{4}$ from 13.5 to $11.6 \mathrm{~g} /$ $\mathrm{kg}$ of milk (van Zijderveld et al., 2011). In a study on the effect of grass maturity on enteric $\mathrm{CH}_{4}$, Brask et al. 
(2013) showed that feeding grass silage from an early cut resulted in lower $\mathrm{CH}_{4}$ production $/ \mathrm{kg}$ of ECM than grass silage that was harvested 3 wk later [i.e., 15.6 $\mathrm{g} / \mathrm{kg}$ of ECM compared with $17.8 \mathrm{~g} / \mathrm{kg}$ of ECM (our calculation based on milk yield and $\mathrm{CH}_{4}$ production per day given by Brask et al., 2013)].

Implementing a feeding strategy affects not only enteric $\mathrm{CH}_{4}$ production, but also other GHG emissions along the chain (Van Middelaar et al., 2013a; Williams et al., 2014). To analyze if the strategy results in a net reduction in GHG emission at the chain level; that is, from feed production to milk harvesting, an integrative approach such as life cycle assessment (LCA) is needed (Van Middelaar et al., 2013a). To our knowledge, no study to date has examined the effect of the abovementioned feeding strategies on GHG emissions along the chain.

Insight into the economic effects of a strategy is required to determine whether the strategy has the potential to be used in practice (Hristov et al., 2013a). Farmers are more willing to implement strategies when the economic effects are positive or when the negative effects are small (Vellinga et al., 2011). Cottle et al. (2011) conclude that most strategies to reduce enteric $\mathrm{CH}_{4}$ from ruminants are currently not profitable, which hampers their implementation. The cost-effectiveness of strategies provides insight into the economic effect per unit of GHG emission reduced.

The objective of this study was to analyze the costeffectiveness of 3 feeding strategies to reduce $\mathrm{CH}_{4}$ production, by calculating the economic effect at farm level per unit of net reduction in GHG emissions at the chain level. Strategies evaluated were dietary supplementation of extruded linseed, dietary supplementation of nitrate, and reducing the maturity stage of grass and grass silage. To determine changes in labor income at the farm level and in GHG emissions at the chain level, we used a dairy farm linear programming (LP) model, a mechanistic model to predict enteric $\mathrm{CH}_{4}$ production of dairy cattle, and LCA. Strategies were evaluated for an average Dutch dairy farm on sandy soil.

\section{MATERIALS AND METHODS}

\section{Dairy Farm LP Model}

A dairy farm LP model based on Berentsen and Giesen (1995) was used to simulate a Dutch dairy farm before and after implementing the feeding strategies. The farm production plan was optimized based on the objective to maximize labor income; that is, gross returns minus variable and fixed costs.

The LP model is a static year model and includes all relevant activities and constraints that are common to
Dutch dairy farms, such as on-farm roughage production, purchase of feed, and animal production, including the rearing of young stock. The central element of the model is an average dairy cow of the Holstein-Friesian breed, with a fixed annual milk production, calving in February, and representing the dairy cattle of the farm. The model distinguishes a summer period $(183 \mathrm{~d})$ and winter period (182 d) regarding feeding. Feed requirements (energy and protein) and intake capacity of the average cow were determined using the bio-economic model of Groen (1988). Safety margins for requirements of true protein digested in the small intestine and for RDP balance were set at $100 \mathrm{~g} /$ cow per day. Based on feed restrictions, the LP model matched feed requirements of the cow with on-farm feed production and purchased feed.

On-farm feed production included production of maize silage and production of grass for grazing and silage making. One hectare of maize silage yields $15.5 \mathrm{t}$ of DM per year, which equals 102 GJ of $\mathrm{NE}_{\mathrm{L}}$ (CBS, 2013). Grassland yield depends on the level of $\mathrm{N}$ fertilization, which can vary from 100 to $500 \mathrm{~kg} /$ ha per year. Based on $225 \mathrm{~kg}$ of $\mathrm{N} /$ ha per year, 1 ha of grassland yields 66 GJ of $\mathrm{NE}_{\mathrm{L}}$ /year. Purchased feeds included maize silage, 3 types of concentrates that differed in protein level (i.e., standard, medium, and high), and dietary urea. All dietary options were available in winter and summer, except for fresh grass (available only in summer). Table 1 shows the feed characteristics of the feeds that were available as standard in the model; feed products that were available after implementing the strategies are discussed in the paragraph on feeding strategies. The prices of purchased feeds are shown in Table 2 .

Constraints of the model included fixed resources of the farm (e.g., land area, milk quota, and housing capacity), links between activities (e.g., feed restrictions, link between manure production and application), and environmental policies. Cows were housed in a cubicle system with slatted floors and manure storage under the slats. Produced manure was applied with low emission techniques. The division of manure between grassland and maize land was optimized by the model. Environmental policies included limits to the application of total mineral $\mathrm{N}$ (in the case of manure $\mathrm{N}, 2.2$ $\mathrm{kg}$ of $\mathrm{N} / \mathrm{t}$ was assumed organic $\mathrm{N}$, whereas the rest, depending on $\mathrm{N}$ in the diets, was assumed to be mineral) and phosphate $\left(\mathrm{P}_{2} \mathrm{O}_{5}\right)$ on the farm, and limits to the application of $\mathrm{N}$ from animal manure (Loket, 2012). The latter constraint is based on the European nitrate directive (Directive 91/676/EEC) and includes the derogation regulation, which is specific for a few countries in the EU that have a high proportion of grassland (European Union, 2010). It prescribes that farms with at least $70 \%$ grassland can apply $250 \mathrm{~kg}$ of 
Table 1. Feed characteristics of feeds available as standard in the dairy farm model

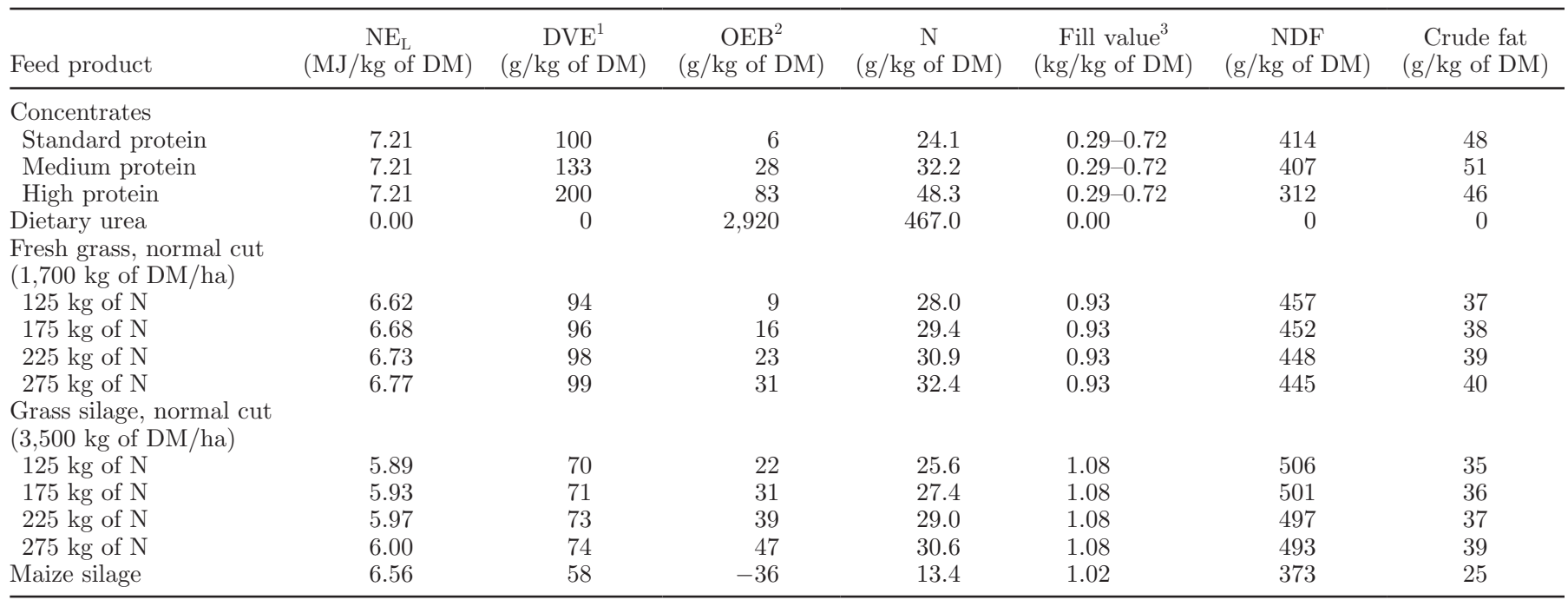

${ }^{1}$ True protein digested in the small intestine according to Dutch standards (Tamminga et al., 1994).

${ }^{2}$ Rumen-degradable protein balance according to Dutch standards (Tamminga et al., 1994).

${ }^{3}$ Fill value per kilogram of DM feed expressed in kilograms of a standard reference feed (see Jarrige, 1988). The fill value of concentrates increases with an increase in concentrate intake.

$\mathrm{N} /$ ha originating from animal manure, instead of 170 $\mathrm{kg}$ of $\mathrm{N} / \mathrm{ha}$ that is prescribed for farms with less than $70 \%$ grassland. For a more detailed description of the model, see Van Middelaar et al. (2013a).

\section{Mechanistic Model for Enteric $\mathrm{CH}_{4}$ Production}

Emission of enteric $\mathrm{CH}_{4}$ from dairy cows was calculated using a mechanistic model originating from Dijkstra et al. (1992), modified and updated by Mills et al. (2001), and applying VFA stoichiometry of Bannink et al. (2006). The model simulates digestion, absorption, and outflow of nutrients in the rumen, small intestine and hindgut, and includes interactions between feed substrates and ruminal microbes, and production of VFA, microbial mass, and di-hydrogen $\left(\mathrm{H}_{2}\right)$. Produc- tion of $\mathrm{CH}_{4}$ is estimated from the $\mathrm{H}_{2}$ balance. Sources of $\mathrm{H}_{2}$ include $\mathrm{H}_{2}$ from production of acetate and butyrate, and from microbial growth with amino acids as $\mathrm{N}$ source. Sinks of $\mathrm{H}_{2}$ include $\mathrm{H}_{2}$ used for production of propionate and valerate, for microbial growth with ammonia as $\mathrm{N}$ source, and for biohydrogenation of lipids. The surplus $\mathrm{H}_{2}$ is assumed to be completely converted into $\mathrm{CH}_{4}$.

To calculate the effect of dietary supplementation of extruded linseed and nitrate on enteric $\mathrm{CH}_{4}$ production, additional calculations were required. These calculations are described in the section on feeding strategies.

\section{LCA}

Life cycle assessment, an internationally accepted and standardized method (ISO 14040 and ISO 14044;

Table 2. Prices and emission factors of purchased feeds

\begin{tabular}{lcc}
\hline Feed & $\begin{array}{c}\text { Price } \\
(€ / \mathrm{t} \text { of } \mathrm{DM})\end{array}$ & $\begin{array}{c}\text { Emission factor } \\
\left(\mathrm{kg} \text { of CO} \mathrm{C}_{2} \mathrm{e} / \mathrm{t} \text { of DM }\right)^{1}\end{array}$ \\
\hline $\begin{array}{l}\text { Standard feeds } \\
\text { Maize silage }\end{array}$ & 148 & 182 \\
$\quad$ Concentrates & 244 & 748 \\
$\quad$ Standard protein & 261 & 768 \\
$\quad$ Medium protein & 322 & 801 \\
$\quad$ High protein & 528 & 1,650 \\
Urea & & 1,174 \\
Feeds introduced with strategies & $674^{2}$ & 727 \\
$\quad$ Extruded linseed product & & \\
Nitrate source & & \\
${ }^{1} \mathrm{CO}_{2} \mathrm{e}=\mathrm{CO}_{2}$ equivalents. & \\
${ }^{2}$ Based on the price of comparable high-linseed products in the Netherlands. \\
${ }^{3} \mathrm{H}$. B. Perdok, Cargill Animal Nutrition, Velddriel, the Netherlands; personal communication.
\end{tabular}


ISO, 2006a,b), was used to evaluate GHG emissions (including $\mathrm{CO}_{2}, \mathrm{CH}_{4}$, and $\mathrm{N}_{2} \mathrm{O}$ ) along the milk production chain, until the moment that milk leaves the farm gate. Processes included are the extraction of raw materials to produce farm inputs, the manufacturing and distribution of these inputs, and all processes on the dairy farm. Stages related to transport and processing of milk were assumed unaffected by the strategies, and, therefore, not included in the analysis. Different GHG emissions were summed based on their equivalence factor in terms of $\mathrm{CO}_{2}$ equivalents $\left(\mathbf{C O}_{2} \mathbf{e} ; 100-\mathrm{yr}\right.$ time horizon): 1 for $\mathrm{CO}_{2}, 25$ for $\mathrm{CH}_{4}$, and 298 for $\mathrm{N}_{2} \mathrm{O}$ (Forster et al., 2007). After summing emissions, they were allocated to the different outputs of the farm (i.e., milk and meat) based on the relative economic value of these outputs (i.e., economic allocation): $89 \%$ of the emissions were allocated to milk and $11 \%$ to meat. Economic allocation is used frequently in LCA studies of livestock products (De Vries and De Boer, 2010). Emissions were divided by the total amount of fat- and protein-corrected milk (FPCM) and expressed in kilograms of $\mathrm{CO}_{2} \mathrm{e}$ per tonne of FPCM.

Emissions from the production of farm inputs were based on Ecoinvent (2007; synthetic fertilizer, pesticides, tap water, energy sources); on Vellinga et al. (2013; concentrates, dietary urea, milk replacer); and on our own calculations (purchased maize silage). For a detailed description of the calculations, see Van Middelaar et al. (2013a). Final $\mathrm{CO}_{2} \mathrm{e}$ per tonne of DM of purchased feeds are included in Table 2.

Emission of enteric $\mathrm{CH}_{4}$ from young stock was based on the Intergovernmental Panel on Climate Change (IPCC) Tier 2 methods and default values (IPCC, 2006). Emissions of $\mathrm{CH}_{4}$ from manure management were based on national inventory reports; that is, $0.746 \mathrm{~kg}$ of $\mathrm{CH}_{4}$ per $\mathrm{t}$ of manure produced in stables, and 0.110 $\mathrm{kg}$ of $\mathrm{CH}_{4}$ per $\mathrm{t}$ of manure produced during grazing (De $\mathrm{Mol}$ and Hilhorst, 2003). Emissions of $\mathrm{CO}_{2}$ from the combustion of diesel and gas during on-farm processes were based on Ecoinvent (2007). Direct and indirect $\mathrm{N}_{2} \mathrm{O}$ emissions (the latter resulting from volatilization of $\mathrm{NH}_{3}$ and $\mathrm{NO}_{\mathrm{x}}$ and from leaching of $\mathrm{NO}_{3}{ }^{-}$) from manure management and from $\mathrm{N}$ application to the field (including $\mathrm{N}$ from manure, synthetic fertilizers, and crop residues) were based on national inventory reports and IPCC (2006). For a detailed description of the calculations, see Van Middelaar et al. (2013a).

\section{Feeding Strategies}

Extruded Linseed. Extruded linseed (LINS strategy) was added as a commercially available linseed product described by Dang Van et al. (2008), containing $56.0 \%$ crushed linseed, $21.0 \%$ wheat, $15.0 \%$ sunflower cake, $4.5 \%$ field beans, $2.0 \%$ butylated hydroxytoluene, $1.0 \%$ linseed oil, and $0.5 \%$ salt. Table 3 shows feed characteristics of this product, and Table 2 shows prices. Considering that high amounts of dietary fat can have negative effects on DMI, digestibility, and milk production (Grainger and Beauchemin, 2011), 1 $\mathrm{kg}$ of product/cow per day was prescribed in the diet in summer and $2 \mathrm{~kg} / \mathrm{cow}$ per day in winter (the product contains $0.9 \mathrm{~kg}$ of $\mathrm{DM} / \mathrm{kg}$ of product). Addition of dietary fat in the form of extruded linseed reduces enteric $\mathrm{CH}_{4}$ production because unsaturated FA provide an alternative $\mathrm{H}_{2}$ sink and prevent the formation of $\mathrm{CH}_{4}$ from $\mathrm{CO}_{2}$ and $\mathrm{H}_{2}$. In addition, adding fat may primarily inhibit fibrolytic bacteria and cause a shift in VFA production toward propionate, reducing $\mathrm{CH}_{4}$ production (Ellis et al., 2008).

The effect of adding FA in the form of extruded linseed on $\mathrm{CH}_{4}$ production was based on Grainger and Beauchemin (2011). They performed a meta-analysis using data from 27 studies to determine the effect of dietary fat on $\mathrm{CH}_{4}$ production. The reduction in $\mathrm{CH}_{4}$ production was calculated by using the following equation: $y=-0.102 x$, where $y$ is the reduction in enteric $\mathrm{CH}_{4}$ (g/kg of DMI) and $x$ is the total amount of dietary fat added ( $\mathrm{g} / \mathrm{kg}$ of $\mathrm{DM})$.

Emissions related to the production of the extruded linseed product were based on Vellinga et al. (2013). The method was similar to that was used to calculate the effect of concentrates production. Table 2 shows final $\mathrm{CO}_{2} \mathrm{e}$ per tonne of DM.

Nitrate. A nitrate source $\left[5 \mathrm{Ca}\left(\mathrm{NO}_{3}\right)_{2} \cdot \mathrm{NH}_{4} \mathrm{NO}_{3} \cdot 10 \mathrm{H}_{2} \mathrm{O}\right.$; $75 \% \mathrm{NO}_{3}$ in $\left.\mathrm{DM}\right]$ was added at $1 \%$ of dietary $\mathrm{DM}$ (NITR strategy). Table 3 shows feed characteristics of this nitrate source, and Table 2 shows prices. In the rumen, nitrate is reduced to nitrite and, subsequently, nitrite is reduced to ammonia. These processes provide an alternative $\mathrm{H}_{2}$ sink that is energetically more favorable than reduction of $\mathrm{CO}_{2}$ to $\mathrm{CH}_{4}$ (Ungerfeld and Kohn, 2006).

The effect of dietary nitrate on $\mathrm{CH}_{4}$ production was based on van Zijderveld (2011). Stoichiometrically, a reduction in $\mathrm{CH}_{4}$ of $0.258 \mathrm{~g} / \mathrm{g}$ of nitrate is expected. In vivo, efficiency of $\mathrm{CH}_{4}$ reduction decreases with increased levels of nitrate intake according to the following equation: $y=-0.17 x+1.13$, where $y$ is the actual reduction in enteric $\mathrm{CH}_{4}$ expressed as a fraction of the reduction potential according to stoichiometry and $x$ is the amount of nitrate expressed in grams per kilogram of metabolic weight $\left(\mathrm{kg}^{0.75}\right)$ per day. The BW of the cow was assumed to be $650 \mathrm{~kg}$, which equals a metabolic weight of $129 \mathrm{~kg}$.

Emissions related to the production of dietary nitrate were based on Ecoinvent (2007). Table 2 shows final $\mathrm{CO}_{2} \mathrm{e}$ per tonne of DM. 
Table 3. Feed characteristics of feeds available after implementing the strategies

\begin{tabular}{|c|c|c|c|c|c|c|c|}
\hline Strategy/feed product ${ }^{1}$ & $\begin{array}{c}\mathrm{NE}_{\mathrm{L}} \\
(\mathrm{MJ} / \mathrm{kg} \text { of } \mathrm{DM})\end{array}$ & $\begin{array}{c}\mathrm{DVE}^{2} \\
(\mathrm{~g} / \mathrm{kg} \text { of } \mathrm{DM})\end{array}$ & $\begin{array}{c}\mathrm{OEB}^{3} \\
(\mathrm{~g} / \mathrm{kg} \text { of } \mathrm{DM})\end{array}$ & $\begin{array}{c}\mathrm{N} \\
(\mathrm{g} / \mathrm{kg} \text { of } \mathrm{DM})\end{array}$ & $\begin{array}{c}\text { Fill value }^{4} \\
(\mathrm{~kg} / \mathrm{kg} \text { of } \mathrm{DM})\end{array}$ & $\begin{array}{c}\mathrm{NDF} \\
(\mathrm{g} / \mathrm{kg} \text { of } \mathrm{DM})\end{array}$ & $\begin{array}{c}\text { Crude fat } \\
(\mathrm{g} / \mathrm{kg} \text { of } \mathrm{DM})\end{array}$ \\
\hline \multicolumn{8}{|l|}{ LINS } \\
\hline $\begin{array}{l}\text { Extruded linseed product } \\
\text { NITR }\end{array}$ & 10.51 & 96 & 87 & 36.9 & 0.29 & 209 & 236 \\
\hline Nitrate & 0.00 & 0 & 1,170 & 187.3 & 0.00 & 0 & 0 \\
\hline \multicolumn{8}{|l|}{ GMS $^{5}$} \\
\hline \multicolumn{8}{|l|}{$\begin{array}{l}\text { Fresh grass, early cut } \\
(1,400 \mathrm{~kg} \text { of } \mathrm{DM} / \mathrm{ha})\end{array}$} \\
\hline $225 \mathrm{~kg}$ of $\mathrm{N}$ & 6.77 & 100 & 26 & 31.9 & 0.93 & 433 & 40 \\
\hline $275 \mathrm{~kg}$ of $\mathrm{N}$ & 6.82 & 102 & 35 & 33.5 & 0.93 & 430 & 41 \\
\hline \multicolumn{8}{|l|}{$\begin{array}{l}\text { Grass silage, early cut } \\
(3,000 \mathrm{~kg} \text { of } \mathrm{DM} / \mathrm{ha})\end{array}$} \\
\hline $125 \mathrm{~kg}$ of $\mathrm{N}$ & 5.96 & 73 & 27 & 27.6 & 1.08 & 488 & 36 \\
\hline $175 \mathrm{~kg}$ of $\mathrm{N}$ & 6.01 & 74 & 38 & 29.5 & 1.08 & 484 & 38 \\
\hline
\end{tabular}

${ }^{1}$ LINS = feeding an extruded linseed product $(1 \mathrm{~kg} / \mathrm{cow}$ per day in summer and $2 \mathrm{~kg} / \mathrm{cow}$ per day in winter $) ;$ NITR $=$ feeding a nitrate source $(1 \%$ of DM $) ;$ GMS $=$ reducing maturity stage of grass and grass silage.

${ }^{2}$ True protein digested in the small intestine according to Dutch standards (Tamminga et al., 1994).

${ }^{3}$ Rumen-degradable protein balance according to Dutch standards (Tamminga et al., 1994).

${ }^{4}$ Fill value per kilogram of feed expressed in kilograms of a standard reference feed (see Jarrige, 1988).

${ }^{5}$ Feed characteristics of grass and grass silage were based on national reports that describe characteristics of grass and grass silage at different DM yields (CVB, 2011). Missing values were interpolated assuming a linear relation between 2 values.

Grass Maturity Stage. Reducing the maturity stage of grass and grass silage (GMS strategy) results in a lower DM per hectare per year but increases grass quality in terms of energy and protein content per kilogram of DM. Total yield in megajoules of $\mathrm{NE}_{\mathrm{L}}$ per hectare per year was assumed to remain unchanged. In the reference situation, grazing was applied at 1,700 $\mathrm{kg}$ of DM/ha and harvesting at $3,500 \mathrm{~kg}$ of DM/ha (Berentsen and Giesen, 1995). After implementing the strategy, grazing was applied at 1,400 $\mathrm{kg}$ of $\mathrm{DM} / \mathrm{ha}$ and harvesting at $3,000 \mathrm{~kg}$ of $\mathrm{DM} / \mathrm{ha}$. Table 3 shows feed characteristics of less-mature grass and grass silage. These less-mature grass products have a lower NDF and higher protein and fat contents compared with grass products in the reference situation (based on CVB, 2011). Feeding less-mature grass, therefore, may shift the profile of VFA in the rumen toward higher propionic acid levels, and consequently reduce the production of enteric $\mathrm{CH}_{4}$ per unit of net energy in feed or milk. Less-mature grass products, moreover, have a higher digestibility. Assuming a constant milk production, a higher digestibility in combination with the higher nutritional value will reduce total DMI and, as a result, lower enteric $\mathrm{CH}_{4}$ production. Costs per grass cut were assumed to be the same as in the reference situation. Due to a lower DM yield per grass cut, the number of cuts per year increased.

\section{Setup of the Analysis}

We evaluated the cost-effectiveness of the 3 strategies for an average Dutch dairy farm on sandy soil. This average farm had 44.9 ha of land, housing facility for 76 dairy cows with young stock, and a milk quota of 603 t/yr. Milk production per cow was assumed to be constant at $7,968 \mathrm{~kg} / \mathrm{yr}$ ( $4.39 \%$ fat and $3.52 \%$ protein). Data were based on the Farm Accountancy Data Network of the Agricultural Economics Research Institute in the Netherlands (FADN, 2012).

Two additional feeding constraints were considered for all situations. First, the maximum fresh grass intake in summer was assumed to be $12 \mathrm{~kg}$ of $\mathrm{DM} /$ cow per day, because limited grazing was applied (Taweel et al., 2004; Abrahamse et al., 2009). Limited grazing (i.e., grazing during daytime) is the most common grazing regimen on Dutch dairy farms (FADN, 2012). Second, the maximum amount of NPN in the diet was assumed equal to the amount of NPN in the diet supplemented with nitrate.

The reference situation, which included no predefined feeding strategy, was determined by maximizing labor income for this average Dutch dairy farm. Subsequently, 1 of the 3 feeding strategies was introduced. Labor income of the farm was maximized again to determine diets and farm plan after implementing each strategy. 
Cost-Effectiveness. The cost-effectiveness of the feeding strategies represents the cost per unit of GHG reduction. It is calculated by dividing the decrease in labor income of the farm family $(€ / y r)$ by the decrease in GHG emissions at the chain level $\left(\mathrm{kg}\right.$ of $\left.\mathrm{CO}_{2} \mathrm{e} / \mathrm{yr}\right)$. To account for the total reduction in GHG emissions, all emissions at the farm level were considered when calculating the cost-effectiveness, implying that no economic allocation was used.

Uncertainty in Prices and Emission Factors. Prices and emission factors contain uncertainty, which can influence results (Van Middelaar et al., 2013b). To quantify the effect of this uncertainty, an uncertainty analysis was performed. Prices of feed products (i.e., purchased maize silage, concentrates, urea, extruded linseed product, and nitrate) were changed by $\pm 25 \%$, equal to the variation in prices of concentrates observed over the last 10 yr (KWIN-V, 2001-2013). Emissions related to production of these products were also changed by $\pm 25 \%$, equal to the variation in emissions of concentrate ingredients found in literature (Nguyen et al., 2012; Van Middelaar et al., 2013b; Vellinga et al., 2013). Uncertainty related to calculating enteric $\mathrm{CH}_{4}$ production varied between strategies. In the case of LINS, uncertainty was based on Grainger and Beauchemin (2011) and equaled $\pm 14.4 \%$ of the calculated reduction resulting from dietary supplementation of FA. In the case of NITR, uncertainty was based on van Zijderveld et al. (2011) and equaled $\pm 14.2 \%$ of the calculated reduction resulting from adding nitrate. In the case of GMS, uncertainty was based on Bannink et al. (2011) and equaled $\pm 13.0 \%$ of the total enteric $\mathrm{CH}_{4}$ production per tonne of FPCM in the reference situation and after reducing grass maturity. All prices were increased or decreased by $25 \%$ at the same time, because price fluctuations of different products were assumed related. Emission factors were changed independently, because they were assumed to be unrelated.

\section{RESULTS AND DISCUSSION}

\section{Diets, Farm Plan, and Labor Income}

In all situations, the milk quota of $603 \mathrm{t}$ was fully used, resulting in a dairy herd consisting of 75.7 cows and 24.9 young stock units (i.e., 1 unit includes 1 animal $<12 \mathrm{mo}$ and 0.96 animal $>12 \mathrm{mo}$ ). The diet for young stock consisted of milk replacer and concentrates in the first months followed by grass and concentrates during the summer period and maize silage and concentrates during the winter period.

Table 4 shows the diets of the dairy cows and farm plan for the reference situation and the situations after implementing the feeding strategies. In the reference situation, the maximum amount of fresh grass was fed in summer, because this was the cheapest way of feeding. Maize silage was added up to $6.59 \mathrm{~kg}$ of DM/ cow per day in combination with standard protein concentrates and dietary urea. As a result, minimum requirements for energy and RDP were met within the limiting intake capacity. In winter, $2.86 \mathrm{~kg}$ of DM grass silage/cow per day was fed, which was the amount of grass left for ensiling after grazing, in combination with $10.98 \mathrm{~kg}$ DM of maize silage/cow per day. High-protein concentrates and urea were added to meet requirements for energy, RDP, and true protein digested in the small intestine. Seventy percent of the farm land was used as grassland and $30 \%$ as maize land. Labor income of the farm family was $€ 42,605 / \mathrm{yr}$. This matched the average income of a farm family in practice, which was $€ 42,900$ in 2010 (dairy farm on sandy soil; FADN, 2012).

Feeding strategy LINS increased the fat content of the summer diet from $35 \mathrm{~g} / \mathrm{kg}$ of DM (reference situation) to $44 \mathrm{~g} / \mathrm{kg}$ of DM. As a result, total DMI was reduced. The amount of maize silage decreased by 0.52 $\mathrm{kg}$ of $\mathrm{DM} /$ cow per day, standard concentrates and urea were removed from the diet, and $0.04 \mathrm{~kg}$ of $\mathrm{DM} /$ cow per day of high-protein concentrates was added. In winter, dietary fat content increased from $32 \mathrm{~g} / \mathrm{kg}$ of DM in the reference situation to $56 \mathrm{~g} / \mathrm{kg}$ of DM after implementing LINS. As a result, the amount of maize silage decreased by almost $3 \mathrm{~kg}$ of DM/cow per day, and urea was removed from the diet. The amount of high-protein concentrates remained to fulfill requirements for true protein digested in the small intestine. Because of the dietary changes, the amount of purchased maize silage and concentrates decreased. Labor income was reduced to $€ 26,564 / \mathrm{yr}$. This reduction was caused almost completely by the relatively high costs of the extruded linseed product compared with the costs of maize silage and concentrates.

Feeding strategy NITR resulted in a dietary NPN level of $37 \mathrm{~g} /$ cow per day in summer, and $31 \mathrm{~g} /$ cow per day in winter, being the maximum amount of dietary NPN allowed. As a result, urea was removed from the diet. No other dietary changes occurred. Because of an increase in dietary $\mathrm{N}$ content, the amount of $\mathrm{N}$ in manure increased. As a result, the amount of synthetic fertilizer decreased. No other changes in farm production plan occurred. When application standards for animal manure would be restricting, feeding nitrate could result in a situation where manure has to be removed from the farm or additional dietary changes would be required to reduce the amount of $\mathrm{N}$ in manure. This was not the case in the present study. Labor income was decreased to $€ 37,142 / y r$. This reduction was caused by the higher costs of dietary nitrate compared with urea. 
Table 4. Diets and farm plan for the reference situation (REF) and after implementing 1 of the 3 strategies

\begin{tabular}{|c|c|c|c|c|}
\hline \multirow[b]{2}{*}{ Diet/farm plan } & \multirow[b]{2}{*}{ REF } & \multicolumn{3}{|c|}{ Strategy ${ }^{1}$} \\
\hline & & LINS & NITR & GMS \\
\hline \multicolumn{5}{|c|}{ Diet dairy cows: summer ( $\mathrm{kg}$ of $\mathrm{DM} / \mathrm{cow}$ per day) } \\
\hline Grass (grazed) & 12.00 & 12.00 & 12.00 & 12.00 \\
\hline Maize silage & 6.59 & 6.07 & 6.59 & 6.62 \\
\hline \multicolumn{5}{|l|}{ Concentrates } \\
\hline Standard protein & 0.88 & - & 0.88 & 0.78 \\
\hline High protein & - & 0.04 & - & - \\
\hline Urea & 0.02 & - & - & 0.01 \\
\hline Extruded linseed product & - & 0.90 & - & - \\
\hline Nitrate & - & - & 0.20 & - \\
\hline Diet restricted by: ${ }^{2}$ & $\mathrm{E}, \mathrm{I}, \mathrm{R}$ & $\mathrm{E}, \mathrm{T}$ & $\mathrm{E}, \mathrm{I}$ & $\mathrm{E}, \mathrm{I}, \mathrm{R}$ \\
\hline \multicolumn{5}{|c|}{ Diet dairy cows: winter ( $\mathrm{kg}$ of DM/cow per day) } \\
\hline Grass silage & 2.86 & 2.86 & 2.86 & 2.75 \\
\hline Maize silage & 10.98 & 8.14 & 10.98 & 11.09 \\
\hline Concentrates high protein & 2.40 & 2.36 & 2.40 & 2.37 \\
\hline Urea & 0.06 & - & - & 0.06 \\
\hline Extruded linseed product & - & 1.80 & - & - \\
\hline Nitrate & - & - & 0.16 & - \\
\hline Diet restricted by: ${ }^{2}$ & $\mathrm{E}, \mathrm{R}, \mathrm{T}$ & $\mathrm{E}, \mathrm{T}$ & $\mathrm{E}, \mathrm{T}$ & $\mathrm{E}, \mathrm{R}, \mathrm{T}$ \\
\hline \multicolumn{5}{|l|}{ On-farm feed production } \\
\hline Grassland $225 \mathrm{~kg}$ of N (ha) & 31.4 & 31.4 & 31.4 & 31.4 \\
\hline Maize land (ha) & 13.5 & 13.5 & 13.5 & 13.5 \\
\hline \multicolumn{5}{|l|}{ Farm inputs } \\
\hline Synthetic fertilizer ( $\mathrm{kg}$ of $\mathrm{N} / \mathrm{ha}$ ) & 117 & 118 & 111 & 116 \\
\hline Synthetic fertilizer $(\mathrm{kg}$ of $\mathrm{P} / \mathrm{ha})$ & 8 & 7 & 7 & 10 \\
\hline Maize silage $(\mathrm{t}$ of $\mathrm{DM})$ & 96 & 48 & 96 & 98 \\
\hline Concentrates ( $\mathrm{t}$ of $\mathrm{DM})$ & 55 & 43 & 55 & 53 \\
\hline Urea $(\mathrm{t}$ of $\mathrm{DM})$ & 1 & - & - & 1 \\
\hline Extruded linseed product ( $\mathrm{t}$ of $\mathrm{DM}$ ) & - & 38 & - & - \\
\hline Nitrate $(t$ of $D M)$ & - & - & 5 & - \\
\hline Labor income $^{3}(€)$ & 42,605 & 26,564 & 37,142 & 42,142 \\
\hline \multicolumn{5}{|c|}{$\begin{array}{l}{ }^{1} \text { LINS }=\text { feeding an extruded linseed product }(1 \mathrm{~kg} / \mathrm{cow} \text { per day in summer and } 2 \mathrm{~kg} / \mathrm{cow} \text { per day in winter } \\
\text { NITR = feeding a nitrate source }(1 \% \text { of } \mathrm{DM}) ; \mathrm{GMS}=\text { reducing maturity stage of grass and grass silage. } \\
{ }^{2} \text { The diet can be restricted by } \mathrm{E} \text { (energy requirements), R (RDP balance), T (true protein digested in the sma } \\
\text { intestine), or I (intake capacity). } \\
{ }^{3} \text { Milk was sold at a price of } € 310 / \mathrm{t} \text { (Wageningen UR, 2011). Culled cows were sold for } € 525 / \text { cow. Agricultur }\end{array}$} \\
\hline
\end{tabular}

Feeding strategy GMS did not affect the amount of grass in kilograms of $\mathrm{DM} /$ cow per day in the summer diet. Because of a higher energy content and a higher RDP content per kilogram of grass, however, the amount of concentrates and urea decreased slightly and that of maize silage increased slightly. Because total DM yield per hectare of grassland decreased, the amount of grass silage in the winter diet decreased. Maize silage slightly increased, whereas the amount of concentrates and urea remained unchanged. Because of a higher $\mathrm{N}$ and a lower $\mathrm{P}$ content in the diet, the amount of $\mathrm{N}$ in manure increased, whereas the amount of $\mathrm{P}$ decreased. This was reflected by a change in purchased fertilizers. Labor income was reduced to $€ 42,142 / y r$. This reduction was caused mainly by an increase in costs related to grassland management, resulting from an increase in the number of grass cuts per hectare per year. In addition, costs of purchased maize silage increased, whereas costs of purchased concentrates decreased.

\section{GHG Emissions}

Table 5 shows GHG emissions in the reference situation and the effect of implementing the feeding strategies. Emissions in the reference situation were $840 \mathrm{~kg}$ of $\mathrm{CO}_{2} \mathrm{e} / \mathrm{t}$ of FPCM. The most important contributor was enteric $\mathrm{CH}_{4}(52 \%)$, followed by emissions from manure (14\%), on-farm feed production (13\%), purchased feed products (10\%), and synthetic fertilizers (8\%). Emissions per tonne of FPCM were low compared with results in the literature (De Vries and De Boer, 2010; Flysjö et al., 2011; Zehetmeier et al., 2012). The lower emissions per tonne of FPCM have 3 main causes. First, the diets contained relatively high amounts of maize silage and low amounts of concentrates, partly because urea was used. Compared with concentrates, maize silage results in lower emissions during production (see Table 2) and in less enteric $\mathrm{CH}_{4}$ production. Second, we used a mechanistic model to calculate enteric $\mathrm{CH}_{4}$ production, 
Table 5. Greenhouse gas (GHG) emissions for the reference situation (REF) and the effect on emissions of implementing the feeding strategies ${ }^{1}\left(\mathrm{~kg}\right.$ of $\mathrm{CO}_{2} \mathrm{e} / \mathrm{t}$ of $\mathrm{FPCM}^{2}$; based on an economic allocation factor of $89 \%$ )

\begin{tabular}{|c|c|c|c|c|}
\hline \multirow[b]{2}{*}{ Item } & \multirow[b]{2}{*}{$\mathrm{REF}$} & \multicolumn{3}{|c|}{ Strategy } \\
\hline & & LINS & NITR & GMS \\
\hline \multicolumn{5}{|l|}{ Animal emissions } \\
\hline Enteric $\mathrm{CH}_{4}$ emissions: dairy cows ${ }^{3}$ & 360 & -42 & -33 & -10 \\
\hline Enteric $\mathrm{CH}_{4}$ emissions: young stock & 79 & 0 & 0 & 0 \\
\hline Manure $^{4}$ & 114 & 0 & 3 & 1 \\
\hline \multicolumn{5}{|l|}{ On-farm feed production } \\
\hline Grassland $^{5}$ & 70 & 0 & -1 & 0 \\
\hline Maize land ${ }^{6}$ & 40 & -2 & -1 & -1 \\
\hline \multicolumn{5}{|l|}{ Production of farm inputs } \\
\hline Maize silage & 25 & -13 & 0 & 1 \\
\hline Concentrates & 60 & -13 & 0 & -2 \\
\hline Urea & 3 & -3 & -3 & 0 \\
\hline Composed linseed product & - & 63 & - & - \\
\hline Nitrate & - & - & 5 & - \\
\hline Synthetic fertilizer & 65 & 1 & -3 & 0 \\
\hline Other inputs ${ }^{7}$ & 25 & 0 & 0 & 0 \\
\hline Total emissions & 840 & -9 & -32 & -11 \\
\hline
\end{tabular}

${ }^{1}$ LINS = feeding an extruded linseed product $(1 \mathrm{~kg} / \mathrm{cow}$ per day in summer and $2 \mathrm{~kg} / \mathrm{cow}$ per day in winter); $\mathrm{NITR}=$ feeding a nitrate source $(1 \%$ of DM); GMS = reducing maturity stage of grass and grass silage.

${ }^{2}$ Different GHG emissions were summed up based on their equivalence factor in terms of $\mathrm{CO}_{2}$ equivalents $\left(\mathrm{CO}_{2} \mathrm{e}\right.$ ): 1 for $\mathrm{CO}_{2}, 25$ for $\mathrm{CH}_{4}$, and 298 for $\mathrm{N}_{2} \mathrm{O}$ (Forster et al., 2007); FPCM = fat- and protein-corrected milk.

${ }^{3}$ Enteric $\mathrm{CH}_{4}$ production in $\mathrm{g}$ of $\mathrm{CH}_{4}$ /cow per day was REF 428 (summer), 323 (winter); LINS 404 (summer), 260 (winter); NITR 390 (summer), 292 (winter); GMS 418 (summer), 312 (winter).

${ }^{4}$ Including emissions from grazing (about $55 \%$, of which about $97 \% \mathrm{~N}_{2} \mathrm{O}$ and $3 \% \mathrm{CH}_{4}$ ) and from manure storage (about $45 \%$, of which about $12 \% \mathrm{~N}_{2} \mathrm{O}$ and $88 \% \mathrm{CH}_{4}$ ).

${ }^{5}$ Including $\mathrm{N}_{2} \mathrm{O}$ emissions from $\mathrm{N}$ application (about 92\%) and emissions related to combustion of diesel during field work (about $8 \%$ ).

${ }^{6}$ Including $\mathrm{N}_{2} \mathrm{O}$ emissions from $\mathrm{N}$ application (about 80\%) and emissions related to combustion of diesel during field work (about 20\%).

${ }^{7}$ Including milk replacer, bedding material, energy sources, tap water, and machinery for field work.

whereas most other studies use IPCC Tier 2 methods that generally overestimate enteric $\mathrm{CH}_{4}$ (Kebreab et al., 2008; Alemu et al., 2011). Third, unlike most other studies, we used a model farm and calculated feed intake, which may differ from the actual intake and may increase the efficiency of the farm.

The LINS strategy reduced emissions of enteric $\mathrm{CH}_{4}$ from dairy cows by $42 \mathrm{~kg}$ of $\mathrm{CO}_{2} \mathrm{e} / \mathrm{t}$ of FPCM. Because of a decrease in the amount of purchased maize silage, concentrates, and urea, emissions related to the production of these products decreased by $29 \mathrm{~kg}$ of $\mathrm{CO}_{2} \mathrm{e} / \mathrm{t}$ of FPCM in total. Emissions from the production of the extruded linseed product were $63 \mathrm{~kg}$ of $\mathrm{CO}_{2} \mathrm{e} / \mathrm{t}$ of FPCM. Changes in other emissions were minor and related to an increase in the $\mathrm{P}$ content of manure. Overall, emissions were reduced by $9 \mathrm{~kg}$ of $\mathrm{CO}_{2} \mathrm{e} / \mathrm{t}$ of FPCM.

The NITR strategy reduced emissions of enteric $\mathrm{CH}_{4}$ from dairy cows by $33 \mathrm{~kg}$ of $\mathrm{CO}_{2} \mathrm{e} / \mathrm{t}$ of FPCM. Producing nitrate instead of urea increased emissions by $3 \mathrm{~kg}$ of $\mathrm{CO}_{2} \mathrm{e} / \mathrm{t}$ of $\mathrm{FPCM}$. Changes in other emissions were minor and related to an increase in the $\mathrm{N}$ content of manure. Overall, emissions were reduced by $32 \mathrm{~kg}$ of $\mathrm{CO}_{2} \mathrm{e} / \mathrm{t}$ of FPCM.
The GMS strategy reduced emissions of enteric $\mathrm{CH}_{4}$ from dairy cows by $10 \mathrm{~kg}$ of $\mathrm{CO}_{2} \mathrm{e} / \mathrm{t}$ of FPCM. Changes in other emissions were minor and related to changes in the diet and an increase in the $\mathrm{N}$ content of manure. Overall, emissions were reduced by $11 \mathrm{~kg}$ of $\mathrm{CO}_{2} \mathrm{e} / \mathrm{t}$ of FPCM.

\section{Cost-Effectiveness}

The cost-effectiveness of each strategy was as follows: $€ 2,594 / \mathrm{t}$ of $\mathrm{CO}_{2} \mathrm{e}$ for LINS, $€ 241 / \mathrm{t}$ of $\mathrm{CO}_{2} \mathrm{e}$ for NITR, and $€ 57 / \mathrm{t}$ of $\mathrm{CO}_{2} \mathrm{e}$ for GMS. The allowance price of $\mathrm{CO}_{2}$ (i.e., the market value) has been $€ 30 / \mathrm{t}$ of $\mathrm{CO}_{2}$ at its maximum since the introduction of the EU Emissions Trading System in 2005 (Calel, 2013). Compared with this value, the cost-effectiveness of all 3 strategies was very low. No other studies were found that calculated the cost-effectiveness of feeding strategies based on economic optimization.

Figure 1 shows the results of the uncertainty analysis. When we consider only the reduction in labor income; that is, the cost of the strategy (y-axis), we can see that GMS had the lowest costs, followed by NITR and then 


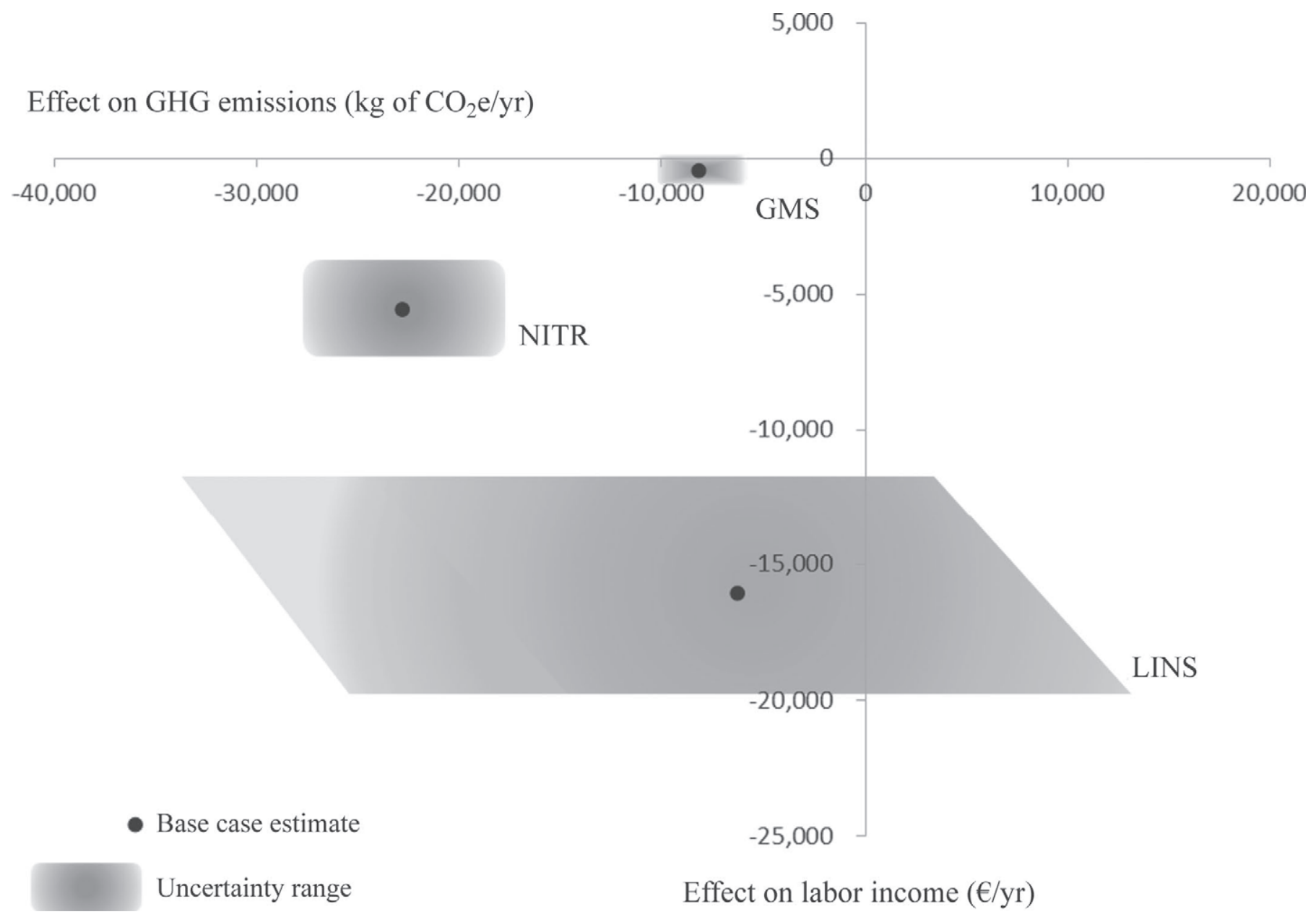

Figure 1. Cost-effectiveness of the feeding strategies: feeding an extruded linseed product (LINS); feeding a dietary nitrate source (NITR); and reducing the maturity stage of grass and grass silage (GMS). GHG = greenhouse gas.

LINS. The uncertainty ranges do not overlap, showing that it is unlikely that a change in price factors would affect the order of the strategies. When we only consider the effect on emissions (x-axis), we can see that the reduction was largest for NITR, followed by GMS and then LINS. The uncertainty range of LINS, however, was very large. A change in emission factors (e.g., by creating production circumstances that result in lower emissions), therefore, could increase the relative importance of LINS compared with GMS and NITR. The LINS strategy had a large uncertainty range because not only was enteric $\mathrm{CH}_{4}$ production affected, but emissions from production of purchased feed products were also affected. In the case of NITR and GMS, changes in emissions other than enteric $\mathrm{CH}_{4}$ production were less important.

The uncertainty range of LINS has the shape of a parallelogram, whereas the uncertainty ranges of NITR and GMS are rectangular. The parallelogram for LINS arises because decreasing the price of purchased feed products also changed the farm plan. Changes in GHG emissions, therefore, not only resulted from a change in underlying emission factors but also from a change in farm plan. Because the change in farm plan resulted in lower emissions, decreasing the prices of purchased feed products resulted in an extra emission reduction, creating the shape of a parallelogram. The most important changes included a reduction in the amount of $\mathrm{N}$ application on grassland from 225 to $200 \mathrm{~kg} / \mathrm{ha}$, a reduction in the amount of synthetic fertilizers (from 118 to $102 \mathrm{~kg}$ of $\mathrm{N} / \mathrm{ha}$ ), and an increase in the amount of purchased maize silage (from 48 to 55 t of DM) and concentrates (from 43 to $45 \mathrm{t}$ of DM) to compensate for a decrease in DM yield per hectare of grassland, and a decrease in nutritional value of grass and grass silage.

Table 6 shows the cost-effectiveness of the strategies including the uncertainty in price and emission factors. Results showed that GMS was most cost-effective, fol- 
Table 6. Cost-effectiveness of the feeding strategies ${ }^{1}\left(€ / t\right.$ of $\mathrm{CO}_{2}$ reduced)

\begin{tabular}{lcc}
\hline Strategy & Cost-effectiveness & $\begin{array}{c}\text { Uncertainty } \\
\text { range }\end{array}$ \\
\hline LINS & 2,594 & {$\left[349 ;{ }^{2}\right]$} \\
NITR & 241 & {$[149 ; 381]$} \\
GMS & 57 & {$[40 ; 86]$} \\
\hline
\end{tabular}

${ }^{1}$ LINS $=$ feeding an extruded linseed product; NITR $=$ feeding a nitrate source; GMS = reducing maturity stage of grass and grass silage.

${ }^{2}$ Emissions increased and therefore the upper limit of the uncertainty range cannot be calculated.

lowed by NITR and then LINS; changes in prices and emission factors are unlikely to change this order.

\section{General Discussion}

Supplementation of an extruded linseed product resulted in a dietary fat content of $44 \mathrm{~g} / \mathrm{kg}$ of DM in summer and $56 \mathrm{~g} / \mathrm{kg}$ of $\mathrm{DM}$ in winter. As a result, enteric $\mathrm{CH}_{4}$ reduced by $1.9 \mathrm{~g} / \mathrm{kg}$ of FPCM. Martin et al. (2008) found a reduction of $4.5 \mathrm{~g} / \mathrm{kg}$ of FCM when adding extruded linseed to achieve a dietary fat content of $57 \mathrm{~g} / \mathrm{kg}$ of DM. The reduction found by Martin et al. (2008), however, mainly originated from a reduction in feed intake and feed digestibility. In addition, milk production decreased significantly in the study of Martin et al. (2008).

The reduction in labor income in case of LINS was very large, resulting in a cost-effectiveness of only $€ 2,594 / \mathrm{t}$ of $\mathrm{CO}_{2} \mathrm{e}$. Because the diets in the reference situation contained relatively high amounts of maize silage and low amounts of concentrates, not only concentrates but also maize silage were replaced by the extruded linseed product. Based on energy content, maize silage is cheaper than concentrates and extruded linseed. The reduction in labor income, therefore, was larger than it would be if the extruded linseed product solely replaced concentrates.

Reducing the maturity stage of grass and grass silage reduced enteric $\mathrm{CH}_{4}$ production by $0.5 \mathrm{~g} / \mathrm{kg}$ of FPCM. Brask et al. (2013) found a reduction of about $2.2 \mathrm{~g}$ of $\mathrm{CH}_{4} / \mathrm{kg}$ of ECM when comparing the effect of feeding early-cut grass silage with late-cut grass silage. Differences in quality (e.g., $\mathrm{NE}_{\mathrm{L}}$ and protein content per $\mathrm{kg}$ of DM) between the 2 silages in that study, however, were much larger than in our study. Because our reference situation was based on a diet using grass products from a normal cut, increasing the grass quality by reducing the maturity stage of grass was limited. This would likely be the case for most farms in practice.

Including high amounts of fat (i.e., $>70 \mathrm{~g} / \mathrm{kg}$ of DM) can negatively affect DMI and fiber digestion in the ru- men (Schroeder et al., 2004; Grainger and Beauchemin, 2011), which can reduce milk yield and affect milk composition. Based on the amounts provided in the present study (i.e., $44 \mathrm{~g} / \mathrm{kg}$ of $\mathrm{DM}$ in summer and $56 \mathrm{~g} / \mathrm{kg}$ of DM in winter), negative effects were not expected. To maximize the reduction in GHG emissions, the amount of extruded linseed could be further increased; that is, up to a dietary fat content of $70 \mathrm{~g} / \mathrm{kg}$ of DM. Increased use of linseed, however, will further decrease labor income. Other fat sources, such as canola oil and cottonseeds, might provide an alternative with better cost-effectiveness.

When energy intake is the limiting factor for milk production, fat supplementation or reducing the maturity stage of grass can increase milk yield per cow (Schroeder et al., 2004; Weiss and Pinos-Rodríguez, 2009). In addition, reducing the maturity stage of grass can increase DMI (Brask et al., 2013), which can also increase milk yield per cow. In our study, milk yield per cow was kept constant and diets were adjusted so that energy requirements were met before and after implementing the strategies. Diets were restricted not only by energy requirements, but also by requirements for RDP balance, intake capacity, and requirements for true protein digested in the small intestine (Table 4). In situations where nutrients other than energy are limiting, fat supplementation is unlikely to increase milk yield. Generally, this will be the case in high-forage diets, whereas in low-forage diets, fat supplementation potentially increases milk yield (Weiss and Pinos-Rodríguez, 2009). Reducing grass maturity offers the potential to increase milk yield in situations where not only energy but also other nutrients and intake capacity are limiting. An increase in milk yield, provided that health and fertility parameters do not decrease, will improve the cost-effectiveness of feeding strategies to reduce GHG emissions (C. Van Middelaar, unpublished data)

Assuming typical human consumption levels in various western countries, milk fat contributes up to $34 \%$ of the daily intake of various long-chain n-3 and n- 6 FA (Van Valenberg et al., 2013). This indicates that a substantial part of the intake of those FA by humans comes from milk fat. Addition of unsaturated FA to a dairy cow's diet can change the FA profile of milk toward less saturated medium-chain FA and more long-chain unsaturated FA (Sterk et al., 2012). This change in milk FA profile is considered beneficial for human health (Kliem and Givens, 2011) and offers an opportunity to increase the revenue per kilogram of milk if consumers are willing to pay a higher price for milk with enhanced proportions of unsaturated FA. In our study, we did not account for this effect, which can occur from LINS and to a lesser extent from GMS (Glasser et al., 2008). A 
positive effect on milk FA profile and the consequential increase in revenue could improve the cost-effectiveness of LINS and GMS.

The dietary nitrate source was added at $1 \%$ of DM. Feeding high levels of nitrate to animals that are not yet adapted can cause methemoglobinemia, a blood disorder in which hemoglobin is unable to release oxygen to the body tissue. Methemoglobinemia can be caused by increased levels of nitrite in the rumen and subsequent absorption due to lack of nitrite-reducing bacterial activity. In a previous study, the same nitrate source was fed to dairy cows at $2.1 \%$ of DM without any negative consequences for animal health. These cows went through an adaptation period of $3 \mathrm{wk}$, with weekly increments of $25 \%$ of the final level (van Zijderveld et al., 2011). Similarly, no negative consequences for animal health were observed in sheep that were fed nitrate at $2.6 \%$ of DM after a similar adaptation regimen of $3 \mathrm{wk}$ (van Zijderveld et al., 2010) and in steers that were fed nitrate at $2.2 \%$ of DM after an adaptation period of 12 d, with 4-d increments of $25 \%$ of the final level (Hulshof et al., 2012). Feeding nitrate at $1 \%$ of DM, therefore, was assumed to pose no risk for methemoglobinemia.

An important source of GHG emissions related to agriculture is land-use change. In this study, we did not include emissions related to land-use change because the strategies did not affect on-farm land use, and the effect on type and amount of purchased feed ingredients related to land-use change was limited (Van Middelaar et al., 2013b).

We evaluated the effect of the 3 strategies for an average Dutch dairy farm on sandy soil. In summer, the main forage type was fresh grass from grazing, whereas in winter it was maize silage. For farms with similar diets, within and outside the Netherlands, the results can be used as an indicator to estimate the impact of the strategies on GHG emissions. For farms using different diets, further analysis is required.

In 2015, the European Union's milk quota system will be abolished, which might change the Dutch dairy system (Louhichi et al., 2010). We assume, however, that our conclusions will remain valid after abolition of the milk quota system. Intensification of Dutch dairy farms will be limited by environmental policies such as the European nitrate directive (EL\&I, 2009) and, given the growing conditions for crop production in the Netherlands, grass is expected to remain the preferred type of forage and major changes in the diet are not expected.

All 3 strategies resulted in a reduction in labor income. This reduces the likelihood of adoption by farmers, because profitability is often the main driver in decision making (Hristov et al., 2013a). Because GMS resulted in the lowest additional costs and the highest cost-effectiveness, this strategy seems to be most promising for application in practice, especially if future legislation or subsidies provide extra stimuli to implement mitigation options.

\section{CONCLUSIONS}

We evaluated the cost-effectiveness of 3 feeding strategies to reduce enteric $\mathrm{CH}_{4}$ production in dairy cows by calculating the effect on profitability at the farm level and on GHG emissions at the chain level. Reducing the maturity stage of grass and grass silage was the most cost-effective ( $€ 57 / \mathrm{t}$ of $\mathrm{CO}_{2} \mathrm{e}$ ), followed by supplementation of dietary nitrate $\left(€ 241 / \mathrm{t}\right.$ of $\left.\mathrm{CO}_{2} \mathrm{e}\right)$ and supplementation of an extruded linseed product $\left(€ 2,594 / \mathrm{t}\right.$ of $\left.\mathrm{CO}_{2} \mathrm{e}\right)$. Supplementation of nitrate resulted in the largest reduction in GHG emissions, but reducing the maturity stage of grass and grass silage resulted in lower costs and better cost-effectiveness. This latter strategy, therefore, was found to be most promising for application in practice.

\section{ACKNOWLEDGMENTS}

We thank CRV BV (Arnhem, the Netherlands), Agrifirm Feed (Apeldoorn, the Netherlands), and the Ministry of Infrastructure and the Environment (Den Haag, the Netherlands) for financially supporting this research. We thank Sander Van Zijderveld and Hink Perdok (both of Cargill Animal Nutrition, Velddriel, the Netherlands) for their help with evaluating the effect of dietary nitrate. We also thank Jeroen Hospers (Wageningen UR, Wageningen, the Netherlands) for his valuable contribution to this study as part of his master's thesis.

\section{REFERENCES}

Abrahamse, P. A., S. Tamminga, and J. Dijkstra. 2009. Effect of daily movement of dairy cattle to fresh grass in morning or afternoon on intake, grazing behaviour, rumen fermentation and milk production. J. Agric. Sci. (Camb.) 147:721-730.

Alemu, A. W., J. Dijkstra, A. Bannink, J. France, and E. Kebreab. 2011. Rumen stoichiometric models and their contribution and challenges in predicting enteric methane production. Anim. Feed Sci. Technol. 166-167:761-778.

Bannink, A., J. Kogut, J. Dijkstra, J. France, E. Kebreab, A. M. Van Vuuren, and S. Tamminga. 2006. Estimation of the stoichiometry of volatile fatty acid production in the rumen of lactating cows. J. Theor. Biol. 238:36-51.

Bannink, A., M. W. van Schijndel, and J. Dijkstra. 2011. A model of enteric fermentation in dairy cows to estimate methane emission for the Dutch National Inventory Report using the IPCC Tier 3 approach. Anim. Feed Sci. Technol. 166-167:603-618.

Berentsen, P. B. M., and G. W. J. Giesen. 1995. An environmentaleconomic model at farm level to analyse institutional and technical change in dairy farming. Agric. Syst. 49:153-175.

Brask, M., P. Lund, A. L. F. Hellwing, M. Poulsen, and M. R. Weisbjerg. 2013. Enteric methane production, digestibility and rumen 
fermentation in dairy cows fed different forages with and without rapeseed fat supplementation. Anim. Feed Sci. Technol. 184:6779 .

Calel, R. 2013. Carbon markets: A historical overview. WIREs Climate Change 4:107-119.

CBS. 2013. CBS Statline - Centraal Bureau voor de Statistiek. Accessed Mar. 25, 2013. http://statline.cbs.nl/StatWeb/selection.

Cottle, D. J., J. V. Nolan, and S. G. Wiedemann. 2011. Ruminant enteric methane mitigation: A review. Anim. Prod. Sci. 51:491-514.

CVB. 2011. CVB Veevoedertabel 2011. Chemische samenstelling en nutritionele waarden van voedermiddelen. Productschap Diervoeder, Den Haag, the Netherlands. (In Dutch).

Dang Van, Q. C., M. Focant, D. Deswysen, E. Mignolet, C. Turu, J Pottier, E. Froidmont, and Y. Larondelle. 2008. Influence of an increase in diet structure on milk conjugated linoleic acid content of cows fed extruded linseed. Animal 2:1538-1547.

De Mol, R. M., and M. A. Hilhorst. 2003. Emissions of methane, nitrous oxide and ammonia from production, storage and transport of manure. Report 2003-03. Institute of Agricultural and Environmental Engineering, Wageningen, the Netherlands. (In Dutch, with summary in English.)

De Vries, M., and I. J. M. De Boer. 2010. Comparing environmental impacts for livestock products: A review of life cycle assessments. Livest. Sci. 128:1-11.

Dijkstra, J., H. D. S. C. Neal, D. E. Beever, and J. France. 1992. Simulation of nutrient digestion, absorption and outflow in the rumen: Model description. J. Nutr. 122:2239-2256.

Ecoinvent. 2007. Ecoinvent Data v2.0: Final Reports Ecoinvent 2007. Swiss Centre for Life Cycle Inventories, Dubendorf, Switzerland.

EL\&I. 2009. Vierde Nederlandse Actieprogramma betreffende de Nitraatrichtlijn (2010-2013). Accessed Feb. 5, 2013. http:// www.rijksoverheid.nl/documenten-en-publicaties/rapporten/ 2009/03/24/vierde-nederlandse-actieprogramma-betreffende-denitraatrichtlijn-2010-2013.html.

Ellis, J. L., J. Dijkstra, E. Kebreab, A. Bannink, N. E. Odongo, B. W. McBride, and J. France. 2008. Aspects of rumen microbiology central to mechanistic modelling of methane production in cattle. J. Agric. Sci. 146:213-233.

European Union. 2010. Commission Decision, amending Decision 2005/880/EC granting a derogation requested by the Netherlands pursuant to Council Directive 91/676/EEC concerning the protection of waters against pollution caused by nitrates from agricultural sources (2010/65/EU). Notified under document C (2010) 606. Official Journal of the European Union 6.2.2010.

FADN (Farm Accountancy Data Network). 2012. Farm Accountancy Data Network. Accessed Apr. 4, 2012. http://www.wageningenur nl/en/Expertise-Services/Research-Institutes/lei/Statistics/ Binternet-1.htm.

Flysjö, A., M. Henriksson, C. Cederberg, S. Ledgard, and J. E. Englund. 2011. The impact of various parameters on the carbon footprint of milk production in New Zealand and Sweden. Agric. Syst. 104:459-469.

Forster, P., V. Ramaswamy, P. Artaxo, T. Berntsen, R. Betts, D. W. Fahey, J. Haywood, J. Lean, D. C. Lowe, G. Myhre, J. Nganga, R. Prinn, G. Raga, M. Schulz, and R. Van Dorland. 2007. Changes in Atmospheric Constituents and in Radiative Forcing. Climate Change 2007: The Physical Science Basis. Contribution of Working Group I to the Fourth Assessment Report of the Intergovernmental Panel on Climate Change. S. Solomon, D. Qin, M. Manning, Z. Chen, M. Marquis, K. B. Averyt, M. Tignor, and H. L. Miller, ed. Cambridge University Press, Cambridge, UK.

Glasser, F., A. Ferlay, and Y. Chilliard. 2008. Oilseed lipid supplements and fatty acid composition of cow milk: A meta-analysis. J. Dairy Sci. 91:4687-4703.

Grainger, C., and K. A. Beauchemin. 2011. Can enteric methane emissions from ruminants be lowered without lowering their production? Anim. Feed Sci. Technol. 166-167:308-320.

Groen, A. F. 1988. Derivation of economic values in cattle breeding: A model at farm level. Agric. Syst. 27:195-213.

Hörtenhuber, S., T. Lindenthal, B. Amon, T. Markut, L. Kirner, and W. Zollitsch. 2010. Greenhouse gas emissions from selected Austri- an dairy production systems - Model calculations considering the effects of land use change. Renew. Agric. Food Syst. 25:316-329.

Hristov, A. N., J. Oh, J. Firkins, J. Dijkstra, E. Kebreab, G. Waghorn, H. P. S. Makkar, A. T. Adesogan, W. Yang, C. Lee, P. J. Gerber, B. Henderson, and J. M. Tricarico. 2013a. Mitigation of methane and nitrous oxide emissions from animal operations: I. A review of enteric methane mitigation options. J. Anim. Sci. 91:5045-5069. http://dx.doi.org/10.2527/jas.2013-6583.

Hristov, A. N., T. Ott, J. Tricarico, A. Rotz, G. Waghorn, A. Adesogan, J. Dijkstra, F. Montes, J. Oh, E. Kebreab, S. J. Oosting, P J. Gerber, B. Henderson, H. P. S. Makkar, and J. Firkins. 2013b. Mitigation of methane and nitrous oxide emissions from animal operations: III. A review of animal management mitigation options. J. Anim. Sci. 91:5095-5113. http://dx.doi.org/10.2527/ jas.2013-6585.

Hulshof, R. B. A., A. Berndt, W. J. J. Gerrits, J. Dijkstra, S. M. van Zijderveld, J. R. Newbold, and H. B. Perdok. 2012. Dietary nitrate supplementation reduces methane emission in beef cattle fed sugarcane-based diets. J. Anim. Sci. 90:2317-2323.

IPCC (Intergovernmental Panel on Climate Change). 2006. Guidelines for National Greenhouse Gas Inventories. Volume 4: Agriculture, Forestry and Other Land Uses. Prepared by the National Greenhouse Gas Inventories Program. H. S. Eggleston, L. Buendia, K. Miwa, T. Ngara, and K. Tanabe, ed. IPCC/Institute for Global Environmental Strategies (IGES), Hayama, Japan.

ISO (International Organization for Standardization). 2006a. ISO 14040: Environmental management-Life cycle assessment: Principles and framework. ISO, Geneva, Switzerland; European Committee for Standardization (CEN), Brussels, Belgium.

ISO (International Organization for Standardization). 2006b. ISO 14044: Environmental management-Life cycle assessment-Requirements and guidelines. ISO, Geneva, Switzerland; European Committee for Standardization (CEN), Brussels, Belgium.

Jarrige, R. 1988. Alimentation des bovins, ovins et caprins. Institut National de la Research Agronomique, Paris, France. (In French).

Kebreab, E., K. Clark, C. Wagner-Riddle, and J. France. 2006. Methane and nitrous oxide emissions from Canadian animal agriculture: A review. Can. J. Anim. Sci. 86:135-158.

Kebreab, E., K. A. Johnson, S. L. Archibeque, D. Pape, and T. Wirth. 2008. Model for estimating enteric methane emissions from United States dairy and feedlot cattle. J. Anim. Sci. 86:2738-2748.

Kliem, K. E., and D. I. Givens. 2011. Dairy products in the food chain: Their impact on health. Annu. Rev. Food Sci. Technol. 2:21-36.

KWIN-V (Kwantitatieve Informative Veehouderij). 2001-2013. Quantitative Livestock Farming Information: 2001-2013. Animal Science Group, Wageningen UR, Wageningen, the Netherlands.

Loket, D. R. 2012. Dienst Regelingen. Ministerie van Economische Zaken, Landbouw, en Innovatie. Dutch Ministry of Agriculture. Accessed Apr. 28, 2012. http://www.hetlnvloket.nl/onderwerpen/ mest/dossiers/dossier/gebruiksruimte-en-gebruiksnormen/ gebruiksnormen.

Louhichi, K., A. Kanellopoulos, S. Janssen, G. Flichman, M. Blanco, H. Hengsdijk, T. Heckelei, P. Berentsen, A. Oude Lansink, and M. Van Ittersum. 2010. FSSIM, a bio-economic farm model for simulating the response of EU farming systems to agricultural and environmental policies. Agric. Syst. 103:585-597.

Martin, C., J. Rouel, J. P. Jouany, M. Doreau, and Y. Chilliard. 2008. Methane output and diet digestibility in response to feeding dairy cows crude linseed, extruded linseed, or linseed oil. J. Anim. Sci. $86: 2642-2650$

Mills, J. A. N., J. Dijkstra, A. Bannink, S. B. Cammell, E. Kebreab, and J. France. 2001. A mechanistic model of whole-tract digestion and methanogenesis in the lactating dairy cow: Model development, evaluation, and application. J. Anim. Sci. 79:1584-1597.

Nguyen, T. T. H., I. Bouvarel, P. Ponchant, and H. M. G. van der Werf. 2012. Using environmental constraints to formulate lowimpact poultry feeds. J. Clean. Prod. 28:215-222.

Schroeder, G. F., G. A. Gagliostro, F. Bargo, J. E. Delahoy, and L. D. Muller. 2004. Effects of fat supplementation on milk production and composition by dairy cows on pasture: A review. Livest. Prod. Sci. 86:1-18. 
Sterk, A., R. Hovenier, B. Vlaeminck, A. M. van Vuuren, W. H. Hendriks, and J. Dijkstra. 2010. Effects of chemically or technologically treated linseed products and docosahexaenoic acid addition to linseed oil on biohydrogenation of C18:3n-3 in vitro. J. Dairy Sci. 93:5286-5299.

Sterk, A., A. M. Van Vuuren, W. H. Hendriks, and J. Dijkstra. 2012. Effects of different fat sources, technological forms and characteristics of the basal diet on milk fatty acid profile in lactating dairy cows-A meta-analysis. J. Agric. Sci. 150:495-517.

Tamminga, S., W. M. Van Straalen, A. P. J. Subnel, R. G. M. Meijer, A. Steg, C. J. G. Wever, and M. C. Blok. 1994. The Dutch protein evaluation system: The DVE/OEB-system. Livest. Prod. Sci. 40:139-155.

Taweel, H. Z., B. M. Tas, J. Dijkstra, and S. Tamminga. 2004. Intake regulation and grazing behavior of dairy cows under continuous stocking. J. Dairy Sci. 87:3417-3427.

Ungerfeld, E. M., and R. A. Kohn. 2006. The role of thermodynamics in the control of ruminal fermentation. Pages 55-85 in Ruminant Physiology: Digestion, Metabolism and Impact of Nutrition on Gene Expression, Immunology and Stress. K. Sejrsen, T. Hvelplund, and M. O. Nielsen, ed. Wageningen Academic Publishers, Wageningen, the Netherlands.

Van Middelaar, C. E., P. B. M. Berentsen, J. Dijkstra, and I. J. M. de Boer. 2013a. Evaluation of a feeding strategy to reduce greenhouse emissions from dairy farming: The level of analysis matters. Agric. Syst. 121:9-22.

Van Middelaar, C. E., C. Cederberg, T. V. Vellinga, H. M. G. Van Der Werf, and I. J. M. De Boer. 2013b. Exploring variability in methods and data sensitivity in carbon footprints of feed ingredients. Int. J. Life Cycle Assess. 18:768-782.

van Valenberg, H. J. F., K. A. Hettinga, J. Dijkstra, H. Bovenhuis, and E. J. M. Feskens. 2013. Concentrations of n-3 and n-6 fatty acids in Dutch bovine milk fat and their contribution to human dietary intake. J. Dairy Sci. 96:4173-4181.

van Zijderveld, S. M. 2011. Dietary strategies to reduce methane emissions from ruminants (general discussion, pages 101-102). PhD Thesis. Wageningen University, Wageningen, the Netherlands. van Zijderveld, S. M., W. J. J. Gerrits, J. A. Apajalahti, J. R. Newbold, J. Dijkstra, R. A. Leng, and H. B. Perdok. 2010. Nitrate and sulfate: Effective alternative hydrogen sinks for mitigation of ruminal methane production in sheep. J. Dairy Sci. 93:5856-5866.

van Zijderveld, S. M., W. J. J. Gerrits, J. Dijkstra, J. R. Newbold, R. B. A. Hulshof, and H. B. Perdok. 2011. Persistency of methane mitigation by dietary nitrate supplementation in dairy cows. J. Dairy Sci. 94:4028-4038.

Vellinga, T., M. H. A. de Haan, R. L. M. Schils, A. Evers, and A. van den Pol-van Dasselaar. 2011. Implementation of GHG mitigation on intensive dairy farms: Farmers' preferences and variation in cost effectiveness. Livest. Sci. 137:185-195.

Vellinga, T. V., H. Blonk, M. Marinussen, W. J. van Zeist, and I. J. M. de Boer. 2013. Methodology used in feedprint: A tool quantifying greenhouse gas emissions of feed production and utilization. Wageningen UR Livestock Research, the Netherlands. http://edepot. wur.nl/254098.

Wageningen UR. 2011. Uitgangspunten en normen voor bedrijfsbegrotingen. Accessed Nov. 8, 2011. http://www.livestockresearch.wur. nl/nl/nieuwsagenda/archief/nieuws/2010/Uitgangspunten_en_ normen_vor_bedrijfsbegrotingen_Melkveehouderij.htm.

Weiss, W. P., and J. M. Pinos-Rodríguez. 2009. Production responses of dairy cows when fed supplemental fat in low-and high-forage diets. J. Dairy Sci. 92:6144-6155.

Williams, S. R. O., P. D. Fisher, T. Berrisford, P. J. Moate, and K Reynard. 2014. Reducing methane on-farm by feeding diets high in fat may not always reduce life cycle greenhouse gas emissions. Int. J. Life Cycle Assess. 19:69-78. http://dx.doi.org/10.1007/ s11367-013-0619-8.

Zehetmeier, M., J. Baudracco, H. Hoffmann, and A. Heißenhuber. 2012. Does increasing milk yield per cow reduce greenhouse gas emissions? A system approach. Animal 6:154-166. 